\title{
Helicobacter hepaticus infection in primary hepatocellular carcinoma tissue
}

\author{
Jili Yang ${ }^{1}, \mathrm{PhD}$, Shangwei $\underline{\mathrm{Ji}}^{1}, \mathrm{PhD}$, Yonggui Zhang${ }^{1}, \mathrm{PhD}$, Jiangbin Wang ${ }^{1}$, PhD
}

INTRODUCTION Helicobacter $(H$.$) hepaticus infection causes chronic active hepatitis and induces hepatocellular$ tumours in $\mathrm{A} / \mathrm{JCr}$ mice, but evidence of this in humans is scarce. This study aimed to demonstrate the correlation between $\mathrm{H}$. hepaticus and human primary hepatocellular carcinoma (HCC).

METHODS The sera of 50 patients with primary HCC were tested for the presence of anti- $\mathrm{H}$. pylori and anti$H$. hepaticus immunoglobulin G (IgG) antibodies. The liver tissues of patients who tested positive for serum antibody were analysed for $H$. hepaticus-specific $16 \mathrm{~S}$ rRNA, $H$. hepaticus $c d t B, H$. pylori cagA, $H$. pylori vacA and $H$. pylori ure $C$ genes using polymerase chain reaction.

RESULTS After the anti-H. pylori antibodies in the serum samples were absorbed by $H$. pylori antigen, the antiH. hepaticus IgG serum antibody detection rate was $50.0 \%$ in patients with primary HCC. This was significantly higher $(p<0.001)$ than the detection rate in the benign liver tumour $(7.7 \%)$ and normal liver tissue $(6.3 \%)$ groups. Of the 25 primary HCC samples that tested positive for anti-H. hepaticus IgG serum antibody, the $H$. hepaticus-specific $16 S$ rRNA gene was detected in nine (36.0\%) samples. Sequencing showed that the polymerase chain reaction-amplified product exhibited $95.5 \%-100 \%$ homology to the $\mathrm{H}$. hepaticus-specific $16 \mathrm{~S}$ rRNA gene. Among these nine primary HCC tissue samples, the H. hepaticus cdtB gene was detected in four (44.4\%) samples, while no such expression was observed in the benign liver tumour or normal liver tissue groups.

CONCLUSION The present study identified the presence of $H$. hepaticus infection in patients with primary HCC using serological and molecular biological detection, suggesting that $H$. hepaticus infection may be involved in the progression of HCC.

Keywords: Helicobacter hepaticus, Helicobacter pylori, primary hepatocellular carcinoma

\section{INTRODUCTION}

Primary hepatocellular carcinoma (HCC), the most common malignant tumour of the digestive tract, features long disease duration and poor prognosis, with liver cirrhosis complicating almost all of its malignancies. ${ }^{(1)}$ Studies have indicated that chronic liver damage, caused by various factors, activates oncogenes and inactivates tumour suppressor genes through the signal transduction system and a variety of complicated mechanisms, ultimately resulting in the development of HCC.(2) However, the pathogenesis of primary HCC is still not fully understood. Chronic hepatitis C virus (HCV) and hepatitis B virus (HBV) infections are important pathogenic factors of liver cirrhosis and $\mathrm{HCC}_{\text {, }}^{(1)}$ as are other non-viral factors such as alcohol-related injury, haemoglobin intoxication, primary biliary cirrhosis and aflatoxin use. ${ }^{(3)}$

Epidemiological studies have shown that a majority of liver cirrhosis and HCC cases are associated with chronic viral infections. ${ }^{(3)}$ In contrast, case analyses have revealed no necessary correlation between these diseases and viral infections. ${ }^{(4)}$ Multicentre follow-up studies have demonstrated that liver injury caused by hepatitis virus infection alone is a long-term chronic process that exhibits no correlation with the occurrence of liver cirrhosis. ${ }^{(5-7)}$ Other factors such as gender, race, genetics, age at viral infection and environmental triggers may aggravate hepatitis, and ultimately, induce liver cirrhosis and HCC. However, to date, no definitive conclusions have been drawn. The same carcinogenic factors may result in vastly different clinical manifestations and prognosis in different patients - some may develop HCC, while others may not experience the symptoms of the disease. Therefore, the presence of other pathogenic factors such as bacterial infection, in addition to the virulence of the aforementioned carcinogenic factors and host immune status, has earned high priority in the study of HCC development.

Since its initial identification, $H$. pylori infection has not only been considered a major pathogenic factor for chronic gastritis, peptic ulcer, gastric cancer and mucosa-associated lymphoid tissue lymphoma of the stomach, ${ }^{(8,9)}$ it has also been found to be closely related to chronic liver disease. ${ }^{(10)}$ First discovered in 1992, infection with $H$. hepaticus was shown to cause chronic active hepatitis that ultimately induced the development of hepatocellular tumours in $\mathrm{A} / \mathrm{JCr}$ mice. ${ }^{(11)}$ Therefore, $H$. hepaticus infection is deemed to be an important pathogenic factor for liver cirrhosis and HCC, in addition to hepatitis virus infection. While the DNA of Helicobacter spp. has been detected in the liver and bile

${ }^{1}$ Department of Gastroenterology, China-Japan Union Hospital of Jilin University, Changchun, China

Correspondence: Dr Jiangbin Wang, Professor, Department of Gastroenterology, China-Japan Union Hospital of Jilin University, Xiantai street, No. 126, Changchun 130033, China. sciencel122@126.com 
duct tissues of patients with chronic liver diseases, the specific Helicobacter spp. in question have not been identified.(12-14) This is mainly attributed to the extreme difficulty encountered in the separation of Helicobacter from liver tissues, as well as in the subsequent culture process. The current commonly used molecular biology technique for identifying Helicobacter consists of detecting Helicobacter-specific 16S rRNA genes using polymerase chain reaction (PCR). ${ }^{(15)}$

Although an association between $H$. hepaticus infection and human pancreatic and biliary diseases has been demonstrated using serological analysis with specific antibodies, ${ }^{(16)}$ there is no knowledge regarding $H$. hepaticus infection or its serological detection in human primary HCC. In the present study, we sought to do the following: (a) detect anti-H. pylori and anti-H. hepaticus immunoglobulin (IgG) antibodies in the sera of 50 patients with primary HCC; (b) amplify $H$. hepaticus-specific $16 \mathrm{~S}$ rRNA, $H$. hepaticus cdtB, $H$. pylori cagA, H. pylori vacA and $H$. pylori ure $C$ genes from the liver tissues of patients who tested positive for the serum antibodies; and (c) identify $H$. hepaticus infections in patients with primary HCC.

\section{METHODS}

A total of 50 patients with primary HCC, diagnosed via surgical resection and liver puncture biopsy at the ChinaJapan Union Hospital of Jilin University and Jilin Provincial Cancer Hospital, Changchun, China, between January 2008 and October 2011, were enrolled in the present study. The patients in the study group, who had a mean age of $56.9 \pm 9.5$ (range 36-79) years and consisted of 37 men and 13 women, were assigned to one of two subgroups according to the occurrence of complicating viral hepatitis. Of the 50 patients, 39 were assigned to the complicating viral hepatitis subgroup, while 11 patients were assigned to the non-complicating viral hepatitis subgroup. All patients were diagnosed with primary HCC using pathological or histological examinations.

Two control groups, comprising gender- and agematched patients hospitalised during the study period, were recruited. The first control group - the benign liver tumour group - consisted of 52 patients (39 men, 13 women) with a mean age of $56.6 \pm 9.8$ (range 39-76) years. Of these 52 patients with benign liver tumours, 29 had hepatic haemangioma, 12 had hepatic nodular hyperplasia, 7 had hepatic bile duct adenoma and 4 had hepatocellular adenoma. The second control group - the normal liver tissue group - consisted of 48 patients (36 men, 12 women) who were admitted for liver traumas. These 48 patients had a mean age of $54.8 \pm 11.4$ (range $36-79$ ) years.

Patients with chronic viral hepatitis, liver cirrhosis, alcohol and drug addiction, or autoimmune diseases were excluded from the study. None of the patients included in the study had undergone any antibiotic therapy within the past six months. Written informed consent was obtained from all participants following a detailed description of the study's purpose and potential benefits. This study was approved by the ethics review committee of the China-Japan Union Hospital of Jilin University.

Approximately $2 \mathrm{~mL}$ of peripheral blood serum was collected from all patients and stored at $-80^{\circ} \mathrm{C}$ for subsequent detection. Liver tissues were collected by liver puncture biopsy or surgical resection using colour ultrasonography. The liver tissues of each patient were divided into two pieces: one piece was stored at $-80^{\circ} \mathrm{C}$ and used for the amplification of $H$. hepaticus-specific $16 \mathrm{~S}$ rRNA, $H$. hepaticus cdtB, H. pylori cag $A, H$. pylori vacA and $H$. pylori ure $C$ genes; the other piece was stored in a Brucella medium containing 30\% glycerol and 5\% fetal calf serum at $-80^{\circ} \mathrm{C}$, and used for the separation, culture and identification of Helicobacter spp.

The detection of anti-H. pylori IgG serum antibody was done using an enzyme-linked immunosorbent assay (ELISA) reagent kit (Sangon Biotech Co Ltd, Shanghai, China), while the detection of anti-H. hepaticus IgG serum antibody was done using ELISA reagents prepared in our laboratory. The standard strain of $H$. hepaticus was employed to prepare the antigen that was to be used to coat the wells of the ELISA microtitre plates, while rabbit anti- $H$. hepaticus sera served as positive controls. The tested sera were diluted at a ratio of 1:100, added to the plate wells, detected using horseradish peroxidaseconjugated secondary antibody and visualised using a chromogenic agent. The optical density value was then measured at $450 \mathrm{~nm}$ using a microplate reader. To avoid cross-reaction between the $H$. hepaticus and $H$. pylori antigens, the anti- $H$. hepaticus IgG antibody was only detected after the anti-H. pylori antibodies in the serum samples were absorbed by $H$. pylori antigen. ${ }^{(17,18)}$

DNA samples were extracted from the liver tissues using the 3S-column extraction method, and all reagents used were supplied by Sangon Biotech Co Ltd. PCR amplification was performed with a total volume of $50 \mu \mathrm{L}$, containing $1 \mu \mathrm{L}$ of DNA template, $2.5 \mathrm{U}(0.5 \mu \mathrm{L})$ of Taq DNA polymerase, $5 \mu \mathrm{L}$ of $10 \times$ buffer, $1.8 \mathrm{mmol} / \mathrm{L}$ magnesium chloride, $200 \mu \mathrm{mol} / \mathrm{L}$ deoxynucleotide triphosphates and $0.5 \mathrm{mmol} / \mathrm{L}$ of primers. Approximately $10 \mu \mathrm{L}$ of the PCR product was collected, electrophoresed on agarose gels and visualised. The primer sequences for the amplification of $H$. hepaticus-specific $16 \mathrm{~S}$ rRNA, $H$. hepaticus cdtB, $H$. pylori $\operatorname{cag} A, H$. pylori vacA and $H$. pylori ure $C$ genes, and the $\mathrm{PCR}$ reaction conditions are shown in Table I.

The $H$. hepaticus-specific 16S rRNA-positive product underwent PCR amplification. After which, the resulting product was electrophoresed on gels, purified and sequenced by Takara Biotechnology Co Ltd, Dalian, China. The sequencing results were aligned with the known sequence of $H$. hepaticus-specific 16S rRNA from the 
Table I. Primer sequences and reaction conditions for polymerase chain reaction amplification of genes specific to Helicobacter $(H$.$) spp.$

\begin{tabular}{|c|c|c|c|}
\hline Target gene & Primer sequence & Reaction condition & $\begin{array}{l}\text { Size of target } \\
\text { fragment (bp) }\end{array}$ \\
\hline $\begin{array}{l}\text { H. hepaticus-specific } \\
16 \text { S rRNA }\end{array}$ & $\begin{array}{l}\text { Forward: } \\
5^{\prime} \text {-gga att tct tgg tgt agg ggt-3' } \\
\text { Reverse: } \\
5^{\prime} \text {-cta ggt aag gtt cgc gt-3' }\end{array}$ & $\begin{array}{l}\text { Pre-degeneration at } 94^{\circ} \mathrm{C} \text { for } 4 \mathrm{~min} ; 35 \text { cycles } \\
\text { of degeneration at } 94^{\circ} \mathrm{C} \text { for } 60 \mathrm{~s} \text {, annealing at } \\
54^{\circ} \mathrm{C} \text { for } 100 \mathrm{~s} \text { and elongation at } 72^{\circ} \mathrm{C} \text { for } 100 \mathrm{~s} \text {; } \\
\text { final extension at } 72^{\circ} \mathrm{C} \text { for } 10 \mathrm{~min}\end{array}$ & 395 \\
\hline H. hepaticus cdtB & $\begin{array}{l}\text { Forward: } \\
\text { 5'-gga atc tac aag gtt ctt cag c-3' } \\
\text { Reverse: } \\
5^{\prime} \text {-cca agt tcc cac gta aac tc-3' }\end{array}$ & $\begin{array}{l}\text { Pre-degeneration at } 94^{\circ} \mathrm{C} \text { for } 4 \mathrm{~min} ; 40 \text { cycles } \\
\text { of degeneration at } 94^{\circ} \mathrm{C} \text { for } 15 \mathrm{~s} \text {, annealing at } \\
58^{\circ} \mathrm{C} \text { for } 25 \mathrm{~s} \text { and elongation at } 72^{\circ} \mathrm{C} \text { for } 30 \mathrm{~s} \text {; } \\
\text { final extension at } 72^{\circ} \mathrm{C} \text { for } 15 \mathrm{~min}\end{array}$ & 193 \\
\hline H. pylori cagA & $\begin{array}{l}\text { Forward: } \\
5^{\prime} \text {-ata atg cta aat tag aca act tga } \\
\text { gcg at-3' } \\
\text { Reverse: } \\
\text { 5'-tta gaa taa tca aca aac atc acg } \\
\text { cca t-3' }\end{array}$ & $\begin{array}{l}\text { Pre-degeneration at } 94^{\circ} \mathrm{C} \text { for } 4 \mathrm{~min} ; 30 \text { cycles of } \\
\text { degeneration at } 94^{\circ} \mathrm{C} \text { for } 50 \mathrm{~s} \text {, annealing at } \\
61^{\circ} \mathrm{C} \text { for } 50 \mathrm{~s} \text { and elongation at } 72^{\circ} \mathrm{C} \text { for } 1 \mathrm{~min} \text {; } \\
\text { final extension at } 72^{\circ} \mathrm{C} \text { for } 10 \mathrm{~min}\end{array}$ & 297 \\
\hline H. pylori vacA & $\begin{array}{l}\text { Forward: } \\
\text { 5'-gga gcc cca gga aac att g-3' } \\
\text { Reverse: } \\
5^{\prime} \text {-cat aac tag cgc ctt gca c-3' }\end{array}$ & $\begin{array}{l}\text { Pre-degeneration at } 94^{\circ} \mathrm{C} \text { for } 5 \mathrm{~min} ; 30 \text { cycles } \\
\text { of degeneration at } 94^{\circ} \mathrm{C} \text { for } 50 \mathrm{~s} \text {, annealing at } \\
55^{\circ} \mathrm{C} \text { for } 50 \mathrm{~s} \text { and elongation at } 72^{\circ} \mathrm{C} \text { for } 1 \mathrm{~min} \text {; } \\
\text { final extension at } 72^{\circ} \mathrm{C} \text { for } 10 \mathrm{~min}\end{array}$ & 352 \\
\hline H. pylori ureC & $\begin{array}{l}\text { Forward: } \\
\text { 5'-gga taa gct ttt agg ggt gtt agg gg-3' } \\
\text { Reverse: } \\
\text { 5'-gct tac ttt cta aca cta acg cgc-3' }\end{array}$ & $\begin{array}{l}\text { Pre-degeneration at } 94^{\circ} \mathrm{C} \text { for } 4 \mathrm{~min} \text {; } 35 \text { cycles } \\
\text { of degeneration at } 94^{\circ} \mathrm{C} \text { for } 1 \mathrm{~min} \text {, annealing at } \\
56^{\circ} \mathrm{C} \text { for } 1 \mathrm{~min} \text { and elongation at } 72^{\circ} \mathrm{C} \text { for } 1 \mathrm{~min} \text {; } \\
\text { final extension at } 72^{\circ} \mathrm{C} \text { for } 10 \mathrm{~min}\end{array}$ & 296 \\
\hline
\end{tabular}

GenBank database. Similarly, the PCR amplification of the product that tested positive for the $H$. pylori $\operatorname{cag} A$, vacA and/or ure $C$ genes was done, and the resulting products were electrophoresed on gels and then sequenced. Sequencing results were compared with the known sequence of the H. pylori gene from the GenBank database.

The liver tissues stored at $-80^{\circ} \mathrm{C}$ were added to $1 \mathrm{~mL}$ of sterile physiological saline. After which, the samples were homogenised and coated evenly onto selective and nonselective Brucella agar media. The cultures were incubated at $37^{\circ} \mathrm{C}$ under high humidity in an incubator containing $5 \% \mathrm{O}_{2}, 10 \% \mathrm{CO}_{2}$ and $85 \% \mathrm{~N}_{2}$ for 3-10 days. The suspected bacterial colonies were identified based on colony characteristics, morphology and biochemical reactions, and PCR amplification and sequencing was performed to investigate the presence of $H$. hepaticus in the liver tissues.

All statistical analyses were performed using the Statistical Package for the Social Sciences for Windows version 11.0 (SPSS Inc, Chicago, IL, USA). Differences were tested for statistical significance using two-sided chi-square test and Fisher's exact test. A p-value $<0.05$ was considered to be statistically significant.

\section{RESULTS}

There were no significant differences between the study group and the two control groups in terms of age, gender or severity of liver damage (Table II). However, a significantly higher proportion of patients with abnormal serum aminotransferase levels was observed in the primary HCC group as compared to the benign liver tumour and normal liver tissue groups. Among the patients in the study group, no significant differences in terms of age, gender, severity of liver damage and serum aminotransferase levels were detected between patients with either HBV or HCV infection and those without (Table III).

Anti-H. pylori and anti-H. hepaticus IgG antibodies were detected in the sera of patients in all three groups (primary HCC, benign liver tumour and normal liver tissue groups). However, significantly higher detection rates $(p<0.001)$ for anti-H. pylori $\lg \mathrm{G}(70.0 \%)$ and anti-H. hepaticus $\operatorname{lgG}(50.0 \%)$ antibodies were observed in the primary HCC group than those in the control groups (benign liver tumour: anti-H. pylori IgG 38.5\%, anti-H.hepaticus IgG 7.7\%; normal liver tissue: anti-H. pylori IgG 35.4\%, anti-H. hepaticus IgG $6.3 \%$ ) (Table IV). The detection rates for the two antibodies in the benign liver tumour group were comparable to those in the normal liver tissue group ( $p>0.05$ ). The existence of HBV or $\mathrm{HCV}$ infection in the primary HCC group was not associated with the detection rate of the two antibodies ( $p>0.05)$.

The $H$. pylori cag $A, \operatorname{vac} A$ and ure $C$ genes in the liver tissues of patients with positive anti-H. pylori IgG serum antibody (35 patients with primary HCC, 20 patients with benign liver tumours and 17 patients with normal liver tissue) were amplified using PCR assay. Agarose gel electrophoresis of the PCR amplification products of patients with primary HCC are shown in Fig. 1. The H. pylori gene was detected in the liver tissues of $16(45.7 \%)$ patients with primary HCC - 50.0\% were positive for $H$. pylori cagA, $31.3 \%$ were positive for $H$. pylori vacA and $68.8 \%$ were positive for $H$. pylori ureC (Table $\mathrm{V}$ ). The rate of positive detection of 
Table II. Clinical characteristics of patients in the three groups.

\begin{tabular}{|c|c|c|c|c|}
\hline \multirow[t]{2}{*}{ Characteristic } & \multicolumn{3}{|c|}{ No. of patients (\%) } & \multirow[t]{2}{*}{ p-value } \\
\hline & $\begin{array}{c}\text { Primary HCC } \\
(n=50)\end{array}$ & $\begin{array}{c}\text { Benign liver } \\
\text { tumour }(n=52)\end{array}$ & $\begin{array}{c}\text { Normal liver } \\
\text { tissue }(n=48)\end{array}$ & \\
\hline Mean age \pm SD (yrs) & $56.9 \pm 9.5$ & $56.6 \pm 9.8$ & $54.8 \pm 11.4$ & 0.56 \\
\hline $\begin{array}{l}\text { Gender } \\
\text { Male } \\
\text { Female }\end{array}$ & $\begin{array}{l}37(74.0) \\
13(26.0)\end{array}$ & $\begin{array}{l}39(75.0) \\
13(25.0)\end{array}$ & $\begin{array}{l}36(75.0) \\
12(25.0)\end{array}$ & 0.99 \\
\hline $\begin{array}{l}\text { Pathological diagnosis } \\
\text { Hepatocellular carcinoma } \\
\text { Hepatic haemangioma } \\
\text { Hepatic nodular hyperplasia } \\
\text { Hepatic bile duct adenoma } \\
\text { Hepatocellular adenoma }\end{array}$ & $\begin{array}{l}50(100.0) \\
\quad- \\
- \\
- \\
-\end{array}$ & $\begin{array}{c}- \\
29(55.8) \\
12(23.1) \\
7(13.5) \\
4(7.7)\end{array}$ & $\begin{array}{l}- \\
- \\
- \\
-\end{array}$ & \\
\hline $\begin{array}{l}\text { Severity of liver damage } \\
\text { Grade A } \\
\text { Grade B } \\
\text { Grade C }\end{array}$ & $\begin{aligned} 44 & (88.0) \\
4 & (8.0) \\
2 & (4.0)\end{aligned}$ & $\begin{aligned} 50 & (96.2) \\
2 & (3.8) \\
0 & (0)\end{aligned}$ & $\begin{aligned} 47 & (97.9) \\
1 & (2.1) \\
0 & (0)\end{aligned}$ & 0.08 \\
\hline $\begin{array}{l}\text { Aspartate aminotransferase } \\
\text { Normal } \\
\text { Abnormal }\end{array}$ & $\begin{array}{l}30(60.0) \\
20(40.0)\end{array}$ & $\begin{aligned} 50 & (96.2) \\
2 & (3.8)\end{aligned}$ & $\begin{array}{c}46(95.8) \\
2(4.2)\end{array}$ & $<0.001$ \\
\hline $\begin{array}{l}\text { Alanine aminotransferase } \\
\text { Normal } \\
\text { Abnormal }\end{array}$ & $\begin{array}{l}28(56.0) \\
22(44.0)\end{array}$ & $\begin{aligned} 51 & (98.1) \\
1 & (1.9)\end{aligned}$ & $\begin{array}{c}46(95.8) \\
2(4.2)\end{array}$ & $<0.001$ \\
\hline
\end{tabular}

HCC: hepatocellular carcinoma; SD: standard deviation

Table III. Clinical characteristics of primary HCC patients with and without HBV/HCV infection $(\mathrm{n}=50)$.

\begin{tabular}{|c|c|c|c|}
\hline \multirow[t]{2}{*}{ Characteristic } & \multicolumn{2}{|c|}{ No. of patients (\%) } & \multirow[t]{2}{*}{ p-value } \\
\hline & With HBV/HCV infection $(n=39)$ & No HBV/HCV infection $(n=11)$ & \\
\hline Mean age \pm SD (yrs) & $57.5 \pm 10.2$ & $54.8 \pm 6.8$ & 0.43 \\
\hline $\begin{array}{l}\text { Gender } \\
\text { Male } \\
\text { Female }\end{array}$ & $\begin{array}{r}32(82.1) \\
7(17.9)\end{array}$ & $\begin{array}{l}5(45.5) \\
6(54.5)\end{array}$ & 0.02 \\
\hline $\begin{array}{l}\text { Severity of liver damage } \\
\text { Grade A } \\
\text { Grade B } \\
\text { Grade C }\end{array}$ & $\begin{aligned} 34 & (87.2) \\
4 & (10.3) \\
1 & (2.6)\end{aligned}$ & $\begin{aligned} 10 & (90.9) \\
0 & (0) \\
1 & (9.1)\end{aligned}$ & 0.82 \\
\hline $\begin{array}{l}\text { Aspartate aminotransferase } \\
\text { Normal } \\
\text { Abnormal }\end{array}$ & $\begin{array}{l}22(56.4) \\
17(43.6)\end{array}$ & $\begin{array}{l}8(72.7) \\
3(27.3)\end{array}$ & 0.49 \\
\hline $\begin{array}{l}\text { Alanine aminotransferase } \\
\text { Normal } \\
\text { Abnormal }\end{array}$ & $\begin{array}{l}19(48.7) \\
20(51.3)\end{array}$ & $\begin{array}{l}9(81.8) \\
2(18.2)\end{array}$ & 0.08 \\
\hline
\end{tabular}

HBV: hepatitis B virus; HCC: hepatocellular carcinoma; HCV: hepatitis C virus; SD: standard deviation

H. pylori genes in the primary HCC group was significantly higher $(p=0.05)$ than that in the benign liver tumour $(20.0 \%)$ and the normal liver tissue $(17.6 \%)$ groups. In addition, the rate of positive detection of $H$. pylori genes in liver tissues complicated with HBV or HCV infection (46.4\%) was higher than that in liver tissues without HBV or HCV infection (42.9\%). This difference, however, was not significant $(p>0.05)$.

The $H$. hepaticus-specific 16S rRNA in the liver tissues of patients who tested positive for anti-H. hepaticus IgG serum antibody (25 patients with primary HCC, 4 with benign liver tumour and 3 with normal liver tissue) was amplified using PCR assay. Agarose gel electrophoresis of the PCR amplification products of $H$. hepaticus-specific 16S rRNA and $H$. hepaticus $c d t B$ genes in the liver tissues of patients with primary HCC are shown in Fig. 2. H. hepaticus-specific $16 \mathrm{~S}$ rRNA gene was detected in the liver tissues of $9(36.0 \%)$ patients with primary HCC and 1 (25.0\%) patient with benign liver tumour, but in none of the patients with normal liver tissues (Table VI). The major virulence gene, $H$. hepaticus $c d t B$, was then amplified in the liver tissues that tested positive for the $H$. hepaticus-specific $16 \mathrm{~S}$ rRNA gene.The $H$. hepaticus $c d t B$ gene was detected in the liver tissues of $4(44.4 \%)$ of the 9 patients with primary HCC, and the detection rate was not associated with the presence or absence of HBV or HCV infection. No H. hepaticus $c d t B$ gene expression was detected in the benign liver tumour or normal liver tissue groups.

The sequencing results of the PCR amplification products of the nine $H$. hepaticus-specific 16S rRNA genepositive samples (in the primary HCC group) were compared with the known sequence of $H$. hepaticus-specific $16 \mathrm{~S}$ rRNA gene from the GenBank database. Sequence alignment 
Table IV. Seropositive rate of anti-Helicobacter $(\boldsymbol{H}$.$) pylori and anti-H. hepaticus IgG serum antibodies.$

\begin{tabular}{|c|c|c|c|c|c|c|c|}
\hline \multirow[t]{2}{*}{ Variable } & \multicolumn{4}{|c|}{ Primary HCC } & \multirow{2}{*}{$\begin{array}{c}\text { Benign liver } \\
\text { tumour }(n=52)\end{array}$} & \multirow{2}{*}{$\begin{array}{l}\text { Normal liver } \\
\text { tissue }(n=48)\end{array}$} & \multirow[t]{2}{*}{ p-value* } \\
\hline & $\begin{array}{l}\text { With HBV/HCV } \\
\quad(n=39)\end{array}$ & $\begin{array}{c}\text { No HBV/HCV } \\
(n=11)\end{array}$ & $p$-value & $\begin{array}{c}\text { Total } \\
(n=50)\end{array}$ & & & \\
\hline Positive for anti-H. pylori IgG & $28(71.8)$ & $7(63.6)$ & 0.71 & $35(70.0)$ & $20(38.5)$ & $17(35.4)$ & $<0.001$ \\
\hline Positive for anti-H. hepaticus IgG ${ }^{+}$ & $22(56.4)$ & $3(27.3)$ & 0.09 & $25(50.0)$ & $4(7.7)$ & $3(6.3)$ & $<0.001$ \\
\hline
\end{tabular}

Data is presented as no. (\%). ${ }^{*}$ Comparison among the three patient groups. ${ }^{\dagger}$ After absorption of anti-H. pylori antibody.

HBV: hepatitis B virus; HCC: hepatocellular carcinoma; HCV: hepatitis C virus; IgG: immunoglobulin G

Table V. Genotyping of Helicobacter (H.) pylori vacA, cagA and ureC genes in the liver tissues of patients who tested positive for anti-H. pylori IgG antibody.

\begin{tabular}{|c|c|c|c|c|c|c|}
\hline \multirow[t]{2}{*}{ Variable } & \multicolumn{3}{|c|}{ Primary HCC } & \multirow{2}{*}{$\begin{array}{c}\text { Benign liver } \\
\text { tumour }(n=20)\end{array}$} & \multirow{2}{*}{$\begin{array}{c}\text { Normal liver } \\
\text { tissue }(n=17)\end{array}$} & \multirow[t]{2}{*}{ p-value* } \\
\hline & $\begin{array}{l}\text { With HBV/HCV } \\
\quad(n=28)\end{array}$ & $\begin{array}{c}\text { No HBV/ HCV } \\
(n=7)\end{array}$ & $\begin{array}{c}\text { Total } \\
(n=35)\end{array}$ & & & \\
\hline Positive for $H$. pylori gene & $13(46.4)$ & $3(42.9)$ & $16(45.7)$ & $4(20.0)$ & $3(17.6)$ & 0.05 \\
\hline $\operatorname{cag} A(+)$ & $7(53.8)$ & $1(33.3)$ & $8(50.0)$ & $1(25.0)$ & $1(33.3)$ & 0.62 \\
\hline $\operatorname{vac} A(+)$ & $4(30.8)$ & 1 (33.3) & 5 (31.3) & $1(25.0)$ & 1 (33.3) & 0.96 \\
\hline ureC $(+)$ & $9(69.2)$ & $2(66.7)$ & $11(68.8)$ & $3(75.0)$ & $2(66.7)$ & 0.96 \\
\hline
\end{tabular}

Data is presented as no. (\%). *Comparison among the three patient groups.

HBV: hepatitis B virus; HCC: hepatocellular carcinoma; HCV: hepatitis C virus

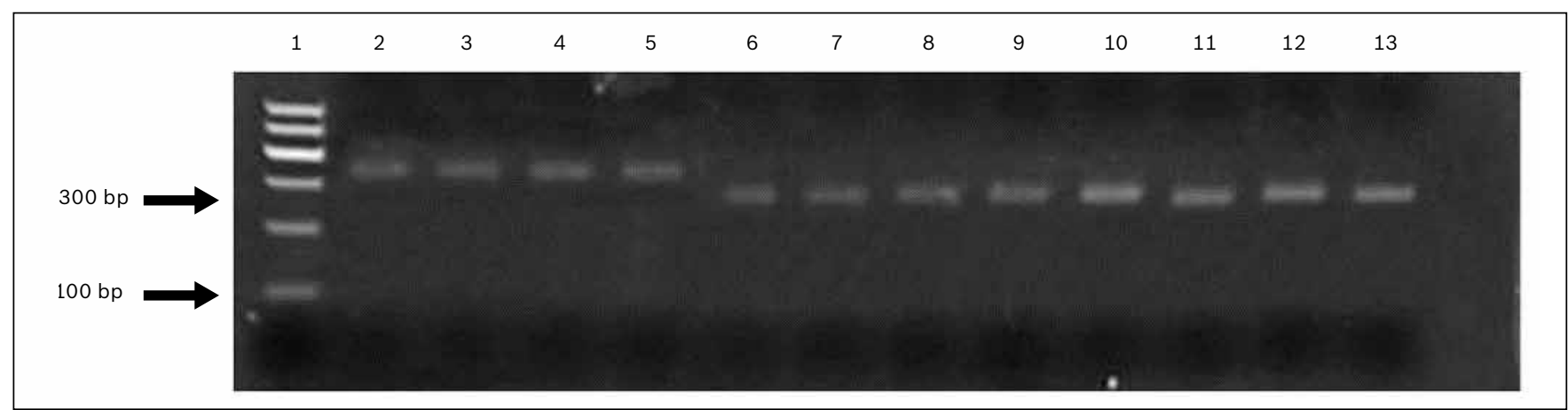

Fig. 1 Agarose gel electrophoresis of the polymerase chain reaction amplification products of $H$. pylori cagA, vacA and ure $C$ genes in the liver tissues of patients with primary hepatocellular carcinoma. Lane 1: 100-bp marker; lanes 2-5: H. pylori vacA gene (352 bp); lanes 6-9: H. pylori cagA gene (297 bp); lanes 10-13: H. pylori ureC gene (296 bp).

revealed that the sequences of the $H$. hepaticus-specific $16 \mathrm{~S}$ rRNA gene fragments detected in the liver tissues of patients with primary HCC were highly similar to that of the $H$. hepaticus-specific $16 \mathrm{~S}$ rRNA gene. In fact, the gene homology ranged from $95.5 \%$ to $100 \%$, with two samples demonstrating $100 \%$ homology. This further confirmed that $H$. hepaticus infection might be present in the liver tissues of patients with primary HCC. Comparisons were also made between the known sequence of the $H$. pylori gene from the GenBank database and the sequencing results of the PCR amplification products of the 16 samples (in the primary HCC group) that tested positive for $H$. pylori $\operatorname{cag} A$, vacA and/or ure $C$ genes. The resulting sequence alignment revealed that the sequences of the positive PCR amplification products exhibited $96.3 \%-100 \%$ homology to the $H$. pylori gene, with four samples showing $100 \%$ homology.

To validate the existence of living Helicobacter spp. in the liver tissues of patients with primary HCC, the microorganisms were separated from the liver tissues of the 50 patients with primary HCC and cultured for 3-10 days. No growth of any suspected bacterial colonies was observed.

\section{DISCUSSION}

$H$. hepaticus infection has been shown to cause chronic active hepatitis and induce $\mathrm{HCC}$ in A/JCr mice. ${ }^{(11)}$ This finding adds to the current understanding of the pathogenic factors of HCC. In addition, mouse strain, genetic background, ${ }^{(19)}$ gender, and age at the time of $H$. hepaticus infection (2-12 weeks) was also shown to determine the final outcome of liver disease. ${ }^{(20)}$ These findings are consistent with some of the characteristics of human chronic liver disease and primary HCC. However, the correlation between $H$. hepaticus and human chronic liver disease is not yet clear. Several studies have shown that the detection rate of Helicobacter spp. DNA in the liver tissues of patients with HCC was much higher than that in control populations. ${ }^{(15,21-29)}$ Most of these detections were made using PCR assays that were based on Helicobacter-specific 16S rRNA, H. pylori cagA, vac $A$ and ure $C$ genes, and genomic sequencing.

The gold diagnostic standard for culturing Helicobacter spp. is very difficult to achieve. ${ }^{(21)}$ Fox et al reported that $H$. hepaticus was cultured from the livers of only $11.5 \%$ of $H$. hepaticus-infected mice, while $H$. hepaticus was detected in $66.6 \%$ of the $H$. hepaticus-infected mice using 
Table VI. Analysis of Helicobacter $(H$.$) hepaticus-specific 16 \mathrm{~S}$ rRNA and $H$. hepaticus cdtB genes in the liver tissues of patients who tested positive for anti-H. hepaticus IgG antibody.

\begin{tabular}{|c|c|c|c|c|c|}
\hline \multirow[t]{2}{*}{ Variable } & \multicolumn{3}{|c|}{ Primary HCC } & \multirow{2}{*}{$\begin{array}{l}\text { Benign liver } \\
\text { tumour }(n=4)\end{array}$} & \multirow{2}{*}{$\begin{array}{l}\text { Normal liver } \\
\text { tissue }(n=3)\end{array}$} \\
\hline & $\begin{array}{l}\text { With HBV or HCV } \\
(n=22)\end{array}$ & $\begin{array}{l}\text { No HBV or HCV } \\
(n=3)\end{array}$ & $\begin{array}{c}\text { Total } \\
(n=25)\end{array}$ & & \\
\hline $\begin{array}{l}\text { Positive for } H \text {. hepaticus- } \\
\text { specific } 16 \text { S rRNA }\end{array}$ & 7 (31.8) & $2(66.7)$ & $9(36.0)$ & $1(25.0)$ & $0(0)$ \\
\hline H. hepaticus cdtB (+) & $3 / 7$ (42.9) & $1 / 2(50.0)$ & $4 / 9(44.4)$ & $0(0)$ & $0(0)$ \\
\hline
\end{tabular}

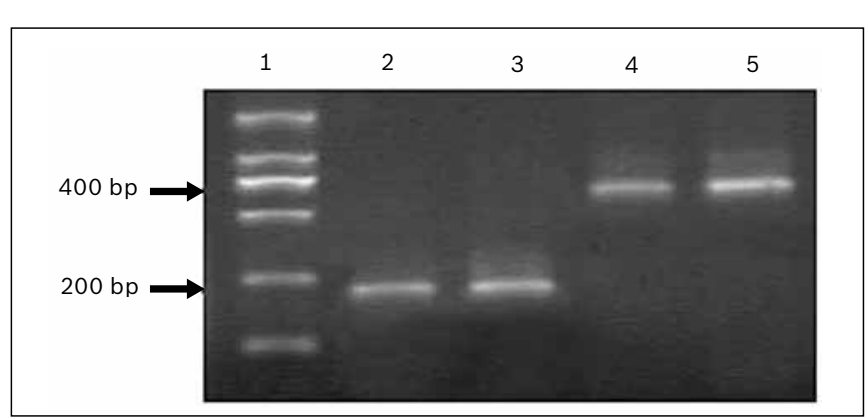

Fig. 2 Agarose gel electrophoresis of the PCR amplification products of $H$. hepaticus-specific $16 \mathrm{~S}$ rRNA and $H$. hepaticus cdtB genes in the liver tissues of patients with primary HCC. Lane 1: 100-bp marker; lanes 2-3: H. hepaticus cdtB gene (193 bp); lanes 4-5: $H$. hepaticus-specific 16S rRNA gene (395 bp)

PCR assay. ${ }^{(30)}$ It has been speculated that Helicobacter spp. present in the liver may lose its ability to survive in an artificial medium. In the present study, the liver tissues of all patients were cultured, but $H$. hepaticus was not separated in any of the cultures. Hence, in effect, the presence of $H$. hepaticus in the liver tissues of patients with liver disease has not been proven with definite experimental evidence to the present day.

Antibody-based serological detection has been widely used for the diagnosis of viral hepatitis. However, the anti- $H$. hepaticus antibody exhibits low specificity since it simultaneously recognises $H$. pylori and $H$. hepaticus antigens. Therefore, it cannot effectively differentiate between the two Helicobacter spp. The association of $H$. hepaticus infection with human biliary and pancreatic diseases has been demonstrated by Western blot analyses using an anti$H$. hepaticus-specific antibody. ${ }^{(16)}$ However, there is no current knowledge regarding the correlation between $H$. hepaticus infection and the serological detection results of human chronic liver diseases and HCC.

The presence of anti- $H$. hepaticus antibodies produced by the host is a powerful piece of experimental evidence for chronic $H$. hepaticus infection. ELISA has been employed to detect anti- $H$. hepaticus serum antibody in patients with liver diseases, and anti- $H$. hepaticus serum antibody concentrations in patients with liver diseases have been found to be significantly higher than those in other disease groups. ${ }^{(31)}$ To increase assay specificity in the present study, the antiH. pylori antibodies in the patients' sera were absorbed by $H$. pylori antigen to remove any possible antigen that could cross-react with the $H$. hepaticus antibody prior to anti-
$H$. hepaticus IgG antibody detection. ELISA showed that the antibody positivity rate of anti- $H$. hepaticus IgG antibody (after the sera were absorbed by the $H$. pylori antigen) in patients with primary HCC $(50.0 \%)$ was significantly higher than that of the benign liver tumour and normal liver tissue groups $(7.7 \%$ and $6.3 \%$, respectively). This finding is similar to that of an earlier study, in which the antibody positivity rate of anti- $H$. hepaticus antibody was $49.3 \%$ in patients with primary HCC. ${ }^{(31)}$ In that study, however, the patients' sera were not absorbed by the $H$. pylori antigen prior to anti-H. hepaticus antibody detection.

In the present study, to identify the existence and species of Helicobacter, detection for DNA fragments of $H$. pylori and $H$. hepaticus in the liver tissues of patients who tested positive for the respective serum antibodies, and detection for the $H$. hepaticus $c d t B$ gene fragment in patients who tested positive for the $H$. hepaticus-specific 16S rRNA gene, were carried out. Of the patients who tested positive for antiH. hepaticus IgG serum antibody, $9(36.0 \%)$ patients with primary HCC and 1 (25.0\%) patient with benign liver tumour tested positive for the $H$. hepaticus-specific 16S rRNA gene. Sequencing of the PCR amplification products of the nine primary HCC samples that were positive for $H$. hepaticusspecific 16S rRNA gene showed that the PCR-amplified products exhibited $95.5 \%-100 \%$ homology to the H. hepaticus-specific $16 \mathrm{~S}$ rRNA gene. Among the nine samples of primary HCC liver tissues that tested positive for the $H$. hepaticus-specific $16 \mathrm{~S}$ rRNA gene, the $H$. hepaticus $c d t B$ gene was detected in $4(44.4 \%)$. No expression of the $H$. hepaticus $c d t B$ gene was observed in the benign liver tumour and normal liver tissue groups. These findings suggest that active $H$. hepaticus infection is present in patients with primary HCC and that anti-H.hepaticus therapy may delay the progression of disease in this cohort.

PCR assays have been shown to detect Helicobacter spp. in the liver tissues of patients with HCC or hepatic cirrhosis complicated by HBV or HCV infection. ${ }^{(29)}$ In one study that used ELISA, using the specific monoclonal antibody HR II-51, the $H$. hepaticus antigen was detected in the sera of patients with common liver diseases, hepatic cirrhosis and hepatitis complicated by HBV or HCV infection. ${ }^{(31)}$ The highest $H$. hepaticus antigen level was found in the sera of patients with hepatic cirrhosis, followed by that in the sera of patients with hepatitis complicated by HBV or HCV 
infection. These groups had $H$. hepaticus antigen levels that were significantly higher than those in patients with common liver diseases. H. hepaticus infection has been suggested to accelerate the progression of $\mathrm{HBV}$ and $\mathrm{HCV}$ infection. (31) The present study showed that the rate of positive detection of anti- $H$. hepaticus IgG serum antibody in patients with primary HCC complicated by HBV or HCV infection (56.4\%) was significantly higher $(p=0.09)$ than that in patients without viral infection (27.3\%). Although this finding is of great interest, studies involving a much larger sample size are required to validate the accuracy of this finding.

In summary, the present study revealed active $H$. hepaticus infection in patients with primary HCC through the use of serological and molecular biology techniques. This finding suggests that $H$. hepaticus may play a role in the disease progression of primary HCC. However, the association of active $H$. hepaticus infection with HCC stage, patient gender and age, and the presence of HBV or HCV infection could not be established due to our study's limited sample size. Further clinical studies with adequate sample sizes and matched control samples are required to reveal the correlation between H. hepaticus and HCC.

\section{ACKNOWLEDGEMENTS}

This work was supported by a grant from the National Science Foundation (no. 3067300).

\section{REFERENCES}

1. El-Serag HB. Hepatocellular carcinoma and hepatitis $C$ in the United States. Hepatology 2002; 36 (5 Suppl 1):S74-83.

2. Nissen NN, Martin P. Hepatocellular carcinoma: the high-risk patient. J Clin Gastroenterol 2002; 35 (5 Suppl 1):S79-85.

3. Smela ME, Currier SS, Bailey EA, Essigmann JM. The chemistry and biology of aflatoxin $\mathrm{B}(1)$ : from mutational spectrometry to carcinogenesis. Carcinogenesis 2001; 22:535-45.

4. Kuper H, Adami HO, Trichopoulos D. Infections as a major preventable cause of human cancer. J Intern Med 2000; 248:171-83.

5. Silini E, Bottelli R, Asti $M$, et al. Hepatitis C virus genotypes and risk of hepatocellular carcinoma in cirrhosis: a case-control study. Gastroenterology 1996; 111:199-205.

6. Wiese M, Berr F, Lafrenz M, Porst H, Oesen U. Low frequency of cirrhosis in a hepatitis $C$ (genotype $1 b$ ) single-source outbreak in Germany: a 20-year multicenter study. Hepatology 2000; 32:91-6.

7. Barrett S, Goh J, Coughlan B, et al. The natural course of hepatitis C virus infection after 22 years in a unique homogenous cohort: spontaneous viral clearance and chronic HCV infection. Gut 2001; 49:423-30.

8. Vandenplas Y. Helicobacter pylori infection. World J Gastroenterol 2000; 6:20-31.

9. Sakai T, Ogura Y, Narita J, et al. Simultaneous early adenocarcinoma and mucosaassociated lymphoid tissue (MALT) lymphoma of the stomach associated with Helicobacter pylori infection. Gastric Cancer 2003; 6:191-6.

10. Vergara M, Calvet X, Roqué M. Helicobacter pylori is a risk factor for peptic ulcer disease in cirrhotic patients. A meta-analysis. Eur J Gastroenterol Hepatol 2002; 14:717-22.

11. Ward JM, Fox JG, Anver MR, et al. Chronic active hepatitis and associated liver tumors in mice caused by a persistent bacterial infection with a novel Helicobacter species. J Natl Cancer Inst 1994; 86:1222-7.

12. Nilsson HO, J Taneera, M Castedal, et al. Identification of Helicobacter pylori and other Helicobacter species by PCR, hybridization, and partial DNA sequencing in human liver samples from patients with primary sclerosing cholangitis or primary biliary cirrhosis. J Clin Microbiol 2000; 38:1072-6.

13. Vorobjova T, I Nilsson, S Terjajev, et al. Serum antibodies to enterohepatic Helicobacter spp. in patients with chronic liver diseases and in a population with high prevalence of $\mathrm{H}$. pylori infection. Dig Liver Dis 2006; 38:171-6.

14. Nilsson I, Kornilovs'ka I, Lindgren S, Ljungh A, Wadström T. Increased prevalence of seropositivity for non-gastric Helicobacter species in patients with autoimmune liver disease. J Med Microbiol 2003; 52:949-53.

15. Huang Y, Fan XG, Wang ZM, et al. Identification of Helicobacter species in human liver samples from patients with primary hepatocellular carcinoma. J Clin Pathol 2004; 57:1273-7.

16. Shimoyama T, Takahashi R, Abe D, et al. Serological analysis of Helicobacter hepaticus infection in patients with biliary and pancreatic diseases. J Gastroenterol Hepatol 2010; 25 Suppl 1:S86-9.

17. Ananieva $\mathrm{O}$, Nilsson I, Vorobjova $\mathrm{T}$, Uibo $\mathrm{R}$, Wadström $\mathrm{T}$. Immune responses to biletolerant Helicobacter species in patients with chronic liver diseases, a randomized population group, and healthy blood donors. Clin Diagn Lab Immunol 2002; 9:1160-4.

18. Nilsson I, Lindgren S, Eriksson S, Wadström T. Serum antibodies to Helicobacter hepaticus and Helicobacter pylori in patients with chronic liver disease. Gut 2000; 46:410-4.

19. Ihrig M, Schrenzel MD, Fox JG. Differential susceptibility to hepatic inflammation and proliferation in AXB recombinant inbred mice chronically infected with Helicobacter hepaticus. Am J Pathol 1999; 155:571-82.

20. Rogers AB, SR Boutin, MT Whary, et al. Progression of chronic hepatitis and preneoplasia in Helicobacter hepaticus-infected $\mathrm{A} / \mathrm{JCr}$ mice. Toxicol Pathol 2004; 32:668-77.

21. Avenaud P, Marais A, Monteiro L, et al. Detection of Helicobacter species in the liver of patients with and without primary liver carcinoma. Cancer 2000; 89:1431-9.

22. Ponzetto A, Pellicano R, Leone N, et al. Helicobacter infection and cirrhosis in hepatitis $\mathrm{C}$ virus carriage: is it an innocent bystander or a troublemaker? Med Hypotheses 2000; 54:275-7.

23. Nilsson HO, Mulchandani R, Tranberg KG, Stenram U, Wadström T. Helicobacter species identified in liver from patients with cholangiocarcinoma and hepatocellular carcinoma. Gastroenterology 2001; 120:323-4.

24. Fan XG, Peng XN, Huang $Y$, et al. Helicobacter species ribosomal DNA recovered from the liver tissue of chinese patients with primary hepatocellular carcinoma. Clin Infect Dis 2002; 35:1555-7.

25. Coppola N, De Stefano G, Marrocco C, et al. Absence of Helicobacter spp. in the liver of patients with primary or metastatic liver cancer. Hepatology 2002; 36:1300-1.

26. Verhoef C, Pot RG, de Man RA, et al. Detection of identical Helicobacter DNA in the stomach and in the non-cirrhotic liver of patients with hepatocellular carcinoma. Eur J Gastroenterol Hepatol 2003; 15:1171-4.

27. Pellicano R, Mazzaferro V, Grigioni WF, et al. Helicobacter species sequences in liver samples from patients with and without hepatocellular carcinoma. World J Gastroenterol 2004; 10:598-601.

28. Ito K, M Nakamura, G Toda, et al. Potential role of Helicobacter pylori in hepatocarcinogenesis. Int J Mol Med 2004; 13:221-7.

29. Rocha M, Avenaud P, Ménard A, Association of Helicobacter species with hepatitis $C$ cirrhosis with or without hepatocellular carcinoma. Gut 2005; 54:396-401.

30. Fox JG, Li X, Yan L, et al. Chronic proliferative hepatitis in $\mathrm{A} / \mathrm{JCr}$ mice associated with persistent Helicobacter hepaticus infection: a model of Helicobacter-induced carcinogenesis. Infect Immun 1996; 64:1548-58.

31. Murakami K, Takahashi R, Ono M, et al. Serodiagnosis of Helicobacter hepaticus infection in patients with liver and gastrointestinal diseases: western blot analysis and ELISA using a highly specific monoclonal antibody for H. hepaticus antigen. J Gastroenterol 2011; 46:1120-6. 